\title{
Level of Thinking in Exams and Assignments as Assessments in the Civil Engineering Department, State University of Malang, Indonesia
}

\author{
Sutrisno, Antelas Eka Winahyo, Ahmad Dardiri \\ Civil Engineering Department \\ State University of Malang \\ Malang, Indonesia \\ sutrisno.ft@um.ac.id
}

\begin{abstract}
This research aimed to shed light on the application of thinking order concepts in exams and assignments based on student needs of hard-skill development. This research was a descriptive ex-post facto research. The samples taken consisted of 36 lecturers in charge of constructing exam questions and assignments for theoretical courses in Department of Civil Engineering. Data were collected through questionnaire and documentation and then analysed using descriptive statistics. Results showed that, first, the exam questions constructed by the lecturers had fairly complied with the Indonesian Qualifications Framework (IQF) Level Six, but the overall proportion of higher-order thinking questions was lacking. Second, the assignments made by the lecturers were relatively good since most parts elicited higherorder thinking and have satisfied the requirements of the IQF Level Six.
\end{abstract}

Keywords—-thinking, exams, assignments

\section{INTRODUCTION}

The indicators of student success in higher education are when graduates secure employment shortly after graduation, in a field related to their degree, and with decent earnings in accordance to their educational level. However, many university graduates are still struggling to achieve certain level of success. Based on data from the Central Bureau of Statistics (BPS) in August 2014, the unemployment rate of university graduates in Indonesia hovered at 9.5\%. The highest number of unemployed graduates was those with a bachelor's degree [1].

The high unemployment rate for university graduates is the result of the mismatch between skills possessed by graduates and those required by employers. This is reflected by the low absorption rate of university graduate into the labour market. The Ministry of Research, Technology and Higher Education of the Republic of Indonesia noted that the number of workers who hold a university degree only amounted to $17.5 \%$ [2]. According to Willis Towers Watson in the Talent Management and Rewards Study since 2014, eight out of ten companies in Indonesia have difficulties finding work-ready university graduates. Most graduates in Indonesia do not have the required qualifications for a job position [1]. Similarly, according to the Chairman of the Standing Committee of the Chamber of Commerce and Industry Education, the condition of higher education in
Indonesia is still very much a subject for discussion and has not satisfied all parties. One of the major problems is the irrelevancy of education to the needs of business and industry. Many companies in Indonesia are having trouble filling positions with highly-qualified employees [3]. The Minister of Research, Technology and Higher Education of Indonesia stated that the quality of university graduates in Indonesia is relatively low due to poor critical thinking and problem-solving skills [4].

The 21st-century learning design is all about problemsolving skills, comprising critical thinking, creativity, innovation, communication, and collaboration [5]. Also, the assessment of the 21 st-century skills should allow students to perform real-world, collaborative, and higher-order thinking tasks [6]. Therefore, the assessment methods require a set of comprehensive criteria with emphasis on skills in high-level cognitive, critical thinking, collaboration, and contextual learning [7]. These abilities are indispensable for the present and the future.

Thinking, according to Bloom's Taxonomy, is classified into six levels, namely knowledge, comprehension, applying, analysing, evaluating, and creating [8]. Experts hold differing opinions on categorising each thinking level as lower-order thinking or higher-order thinking. There are at least three shades of opinions on the matter. Firstly, knowledge, comprehension and application are lower-order thinking skills, while analysis, synthesis, and evaluation are high-level thinking skills [9].

The second view is that lower-order thinking skills (LOTS) include knowledge and comprehension, whereas application, analysis, synthesis, and evaluation belong to higher-order thinking skills (HOTS) $[10,11]$. In fact, highorder thinking skills are reflected by applying, analysing, evaluating, and creating [8]. Level of thinking is viewed regarding the level of questions, i.e. lower-order questions and higher-order questions. Lower-order questions involve knowledge and comprehension levels, while higher-order questions are those at the application, analysis, synthesis, and evaluation levels [12].

Lastly, the experts argued that lower-order thinking is characterised by the application of concepts or knowledge to familiar situations, while higher-order thinking involves solving tasks in new contexts/situations. Therefore, the 
application level often falls into both categories, LOTS or HOTS [13]. An application-level test item belongs to HOTS if it requires the application of knowledge in a new situation, and it is regarded as LOTS if it involves applying knowledge in a familiar situation [14]. Figure 1 illustrates that the application level may belong to LOTS or HOTS.

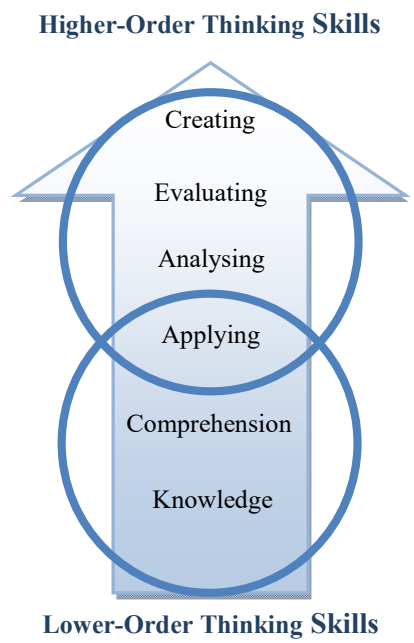

Fig. 1. Categorisation of lots and hots [14]

High-level cognitive skills are demonstrated by critical, logical, reflective, metacognitive, and creative thinking. These skills are activated when students face unfamiliar and complex issues or dilemmas. High-level thinking occurs when a person acquires new information and establish a connection or organises information stored in memory to find possible answers [15].

In other words, higher-order thinking skills cover applying knowledge to new situations, analysing, evaluating, and creating. These higher-order thinking skills should be incorporated in assessment methods - such as written exams or assignments - to provide great support to the improvement of hard skills.

In Indonesia, the graduates' competences of all levels of education - from primary school to higher education-are set forth in the Indonesian Qualifications Framework (IQF) or Kerangka Kualifikasi Nasional Indonesia. The competence level of bachelor's degree (S1) graduates belongs to the IQF Level 6 [16]. Graduates with the IQF Level 6 are expected to be able to (1) apply science, technology, and art within their expertise and adapt to various situations faced; (2) master general and specific theoretical concepts of a certain area of knowledge in depth and formulate procedural problem solving; and (3) take strategic decisions based on information and data analysis and provide guidance in selecting a variety of alternative solutions individually or in groups.

Based on the descriptors of IQF Level 6, students who wish to pursue a bachelor's degree need to involve $\mathrm{C} 3 \mathrm{a}-\mathrm{C} 5$ thinking level-positively skewed distribution (skewed right) with $\mathrm{C} 3 \mathrm{~b}$ as the peak.

There are two fundamentals for determining the assessment criteria: applying the higher-order thinking concepts and adhering to the Indonesian Qualifications Framework. Compelled by the above background, this research aimed to shed light on the application of thinking order concepts in exams and assignments based on students' needs of hard-skill development.

\section{METHOD}

This research is descriptive ex-post facto research. The variables involved in this study were the levels of thinking in two types of assessment, i.e. exams and assignments. This aimed to determine the level of thinking relevant to the hardskill development of Department of Civil Engineering students.

The research population was the assessment of theory courses in the Department of Civil Engineering, Universitas Negeri Malang in 2017. Based on the total number of courses and classes, the samples taken consisted of 36 lecturers or $83.72 \%$ of the assessment processes in the Department of Civil Engineering, which were selected by purposive sampling. The instrument developed in this research was a closed-ended questionnaire using a Likert scale about the level of thinking in the assignments for the whole semester and the final semester exams of each theory course. Data were extracted from each lecturer of the Department of Civil Engineering. The data analysis technique used was descriptive analysis, including mean, percentage, and diagram..

\section{RESULT}

\section{A. Level of Thinking in Exams}

Table 1 shows the result of the descriptive analysis on the exam questions made by the lecturers of the Department of Civil Engineering. The exam questions involved 56.25\% applying (C3), 24.52\% understanding (C2), 16.18\% analysing $(\mathrm{C} 4), 2.36 \%$ remembering $(\mathrm{C} 1)$, and evaluating (C5) is $0.69 \%$; the creating level (C6) was not available.

On average, the exam questions constructed by the lecturers of the Department of Civil Engineering require the application level (C3). The proportion of thinking levels lower than $\mathrm{C} 3$ was $26.88 \%$, while that higher than $\mathrm{C} 3$ was $73.12 \%$. These results indicate that the exam questions have fairly complied with the Indonesian Qualifications Framework Level Six.

TABLE I. PROPORTION OF THINKING LEVEL IN EXAMS

\begin{tabular}{|l|c|c|c|}
\hline Level of Thinking & Proportion (\%) & \multicolumn{2}{|c|}{ Cumulative (\%) } \\
\hline Remembering (C1) & 2.36 & 2.36 & 100.00 \\
Understanding (C2) & 24.52 & 26.88 & 97.64 \\
Applying (C3) & 56.25 & 83.13 & 73.12 \\
Analysing (C4) & 16.18 & 99.31 & 16.87 \\
Evaluating (C5) & 0.69 & 100.00 & 0.69 \\
Creating (C6) & 0.00 & 100.00 & 0.00 \\
\hline Total & 100.00 & \multicolumn{2}{|c|}{} \\
\hline
\end{tabular}

Figure 2 shows the proportion of thinking levels in a bar chart. The application level (C3) was at the peak and the centre of the bar chart, resembling a normal distribution. The distribution resembling a normal curve was also reinforced by the results of the Kolmogorov-Smirnov normality test, i.e. $Z=0.599$ with Asymp. Sig. (2-tailed) $=0.865>0.05$, meaning that the data were normally distributed. Also, the data represented the population of exam questions made by the lecturers of the Department of Civil Engineering. 


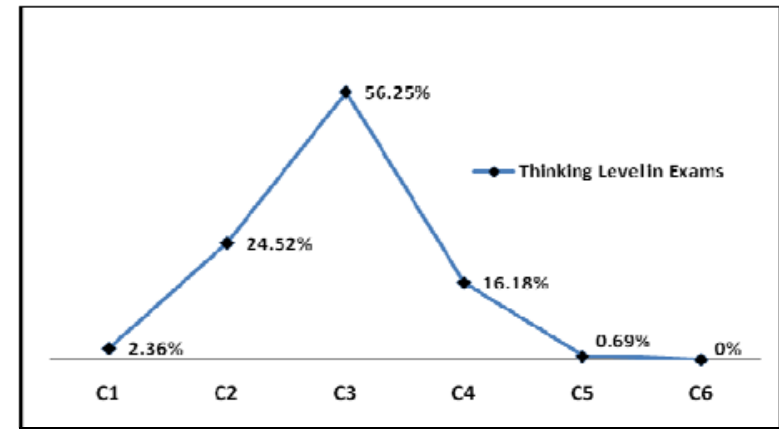

Fig. 2. Diagram Of Thinking Level In Exams

Based on previous theoretical studies, lower-order thinking and higher-order thinking are divided by the application level - applying knowledge to familiar situations (C3a) is LOT, whereas applying knowledge to new situations (C3b) is HOTS. The thinking levels of $\mathrm{C} 1-\mathrm{C} 3 \mathrm{a}$ belong to lower-order thinking, while $\mathrm{C} 3 \mathrm{~b}$ - C6 fall into higher-order thinking. The results of this research showed that the exam questions involved 55.01\% lower-order thing skills and $44.99 \%$ higher-order thinking, as shown in Table 2.

TABLE II. PROPORTION OF LOTS AND HOTS IN EXAMS

\begin{tabular}{|ll|l|l|l|}
\hline \multicolumn{3}{|c|}{ Level of Thinking } & \multicolumn{2}{|l|}{ Proportion (\%) } \\
\hline $\begin{array}{l}\text { Lower } \\
\text { thinking }\end{array}$ & order & Remembering (C1) & 2.36 & 55.01 \\
(LOTS) & & Understanding (C2) & 24.52 & \\
\hline Higher & order & Applying past knowledge (C3a) & 28.13 & \\
thinking & skills & Aplying new knowledge & 28.12 & 44.99 \\
(HOTS) & & Analysing (C4) & 16.18 & \\
& & Evaluating (C5) & 0.69 & \\
& & Creating (C6) & 0.00 & \\
\hline Total & & 100.00 & \\
\hline
\end{tabular}

The results indicate that the exam questions involved only a small proportion of higher-order thinking $(<60 \%)$. In other words, the tests made by the lecturers of the Department of Civil Engineering lacked higher-order thinking questions.

The proportion of higher-order thinking questions was inadequate, particularly in the level of evaluation (only $0.69 \%$ ) and creating (none). Nevertheless, the development of higher-level thinking skills can be encouraged through independent courses and thesis writing.

\section{B. Level of Thinking in Assignments}

The opinion of lecturers under study showed that most assignments have elicited higher-order thinking. The analysis results of lecturers' view on the proportion of high-level thinking questions in assignments are presented in Table 3.

TABLE III. LECTURERS' VIEW ON THE LEVEL OF THINKING IN ASSIGNMENTS

\begin{tabular}{|l|l|}
\hline \multicolumn{1}{|c|}{ Lecturer's View } & \multicolumn{1}{|c|}{ Proportion (\%) } \\
\hline Based on higher-order thinking & 88.89 \\
Not based on higher-order thinking & 5.56 \\
Do not know & 5.55 \\
\hline Total & 100.00 \\
\hline
\end{tabular}

Based on the lecturers' view, a large proportion of assignments have promoted high-order thinking (88.89\%),
$5.56 \%$ were not based on high-order thinking, and 5.55\% were unknown. In other words, $88.89 \%$ assignments involved higher-order thinking skills, while the rest did not require higher-order thinking skills.

As shown in Table $4,11.11 \%$ assessments aimed at $\mathrm{C} 2$, $19.44 \%$ aimed at $\mathrm{C} 3 \mathrm{a}, 61.11 \%$ aimed at $\mathrm{C} 3 \mathrm{~b}, 0 \%$ aimed at $\mathrm{C} 4,5.56 \%$ aimed at $\mathrm{C} 5$, and $2.78 \%$ aimed at C6. In sum, the lecturers' view on the level of thinking in exams differed slightly from the aim of assessment; the proportion of higherlevel thinking skills elicited in assignments according to the lecturers was $88.89 \%$ higher-level thinking while based on the aim of assessment was $69.45 \%$. In other words, the level of thinking involved in the assignments made by the lecturers of the Department of Civil Engineering was categorised as acceptable.

TABLE IV. LEVEL OF THINKING IN ASSIGNMENTS BASED ON AIM OF ASSESSMENT

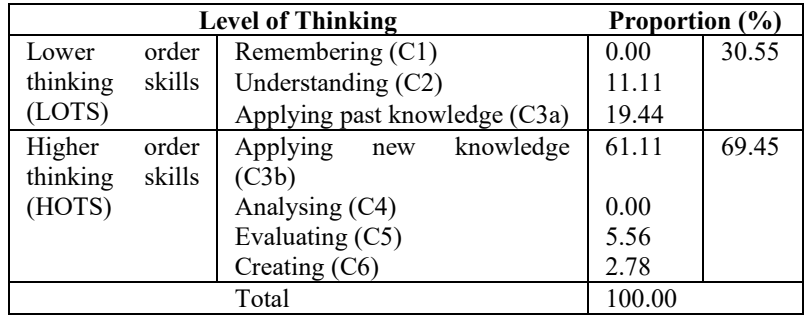

Figure 3 shows the comparison between the lecturers' view and the purpose of assignment regarding the level of thinking in assignments. The chart suggests that the opinion of lecturers on both lower-order thinking and higher-order thinking was more extreme than the aim of assessment.

These analysis results suggest that the assignments made by the lecturers of the Department of Civil Engineering Universitas Negeri Malang were fairly good since most parts elicited higher-order thinking. Thus, such assignments could adequately meet students' needs in the development of higher-order thinking skills to solve problems in future work.

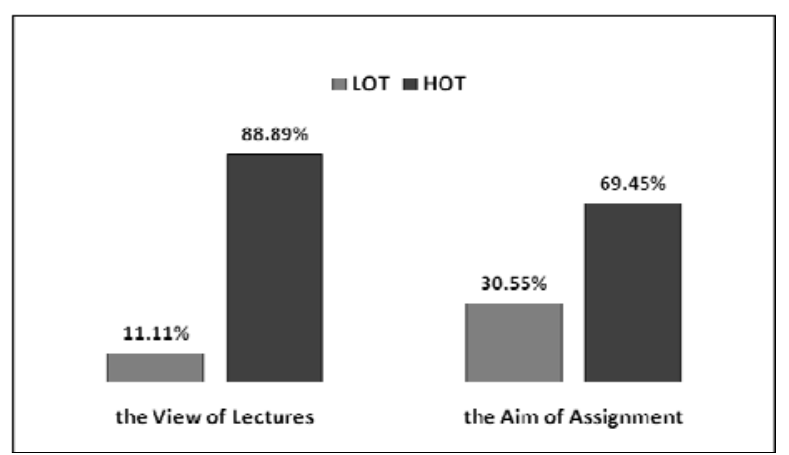

Fig. 3. Lots and hots based on the view of lectures and the aim of assignment

\section{DISCUSSION}

\section{A. Level of Thinking in Exams}

The analysis results showed that the exam questions constructed by the lecturers of the Department of Civil Engineering consisted quite a large number of questions in the levels higher than $\mathrm{C} 3(73.12 \%)$; the proportion of 
thinking levels lower than $\mathrm{C} 3$ was only $26.88 \%$. Based on the descriptors of IQF Level 6 [16], bachelor's degree students require $\mathrm{C} 3 \mathrm{a}-\mathrm{C} 5$ thinking level-positively skewed distribution (skewed right). These results indicate that the exam questions have fairly complied with the Indonesian Qualifications Framework Level Six.

However, the overall proportion of higher-order thinking questions in the exams was categorised as lacking (only 44.99\%). Most test items constructed such as essay and open-ended problem-solving have not extensively promoted higher-order thinking. This result is not far different from the conditions in other universities. A former study found that the technique of writing questions applied by Biology Department students only involved $25 \%$ of their higher-order thinking - the rest was lower-order thinking [17]. Further, the results of student questions consisted of lower-order thinking questions eliciting $\mathrm{C} 1$ and $\mathrm{C} 2$ thinking levels $(53.44 \%)$ and higher-order thinking questions eliciting C3 and C4 thinking levels (46.56\%) [18]. This finding also concurs well with that found in higher education institutions in Thailand; most students there involved only a fair proportion of higher-order thinking skills [19]. Moreover, most exams in the Department of Biology, University of Washington elicited only lower-order thinking [11].

On the whole, judging from the proportion of thinking levels, the exam questions made by the lecturers of the Department of Civil Engineering have fairly satisfied the Indonesian Qualifications Framework Level Six and the needs of Civil Engineering undergraduate students. However, those exams still lacked higher-order thinking questions.

\section{B. Level of Thinking in Assignments}

This analysis results suggest that the assignments made by the lecturers of the Department of Civil Engineering, state university of Malang were fairly good since most parts $(69.45 \%)$ elicited higher-order thinking. Thus, such assignments could adequately meet students' needs in the development of higher-order thinking skills. In fact, the level of thinking in assignments was higher than the exam questions. The exam questions usually consist of multiplechoice items and essays which promote the thinking level of $\mathrm{C} 4$ and $\mathrm{C} 5$ at most, respectively. The assignments, on the other hand, can elicit a higher-order thinking level which is C6.

By doing assignments, students can improve their higherorder thinking and consequently, solve real problems better. Students will have plenty of opportunities to foster creativity in generating innovative solutions. Challenging tasks indeed can promote higher order thinking skills in students. As established by BAN-PT, the proportion of assignments shall be at least $20 \%$; reaching $50 \%$ or greater is suggested [20].

Most engineering students utilise higher-order thinking skills to deal with problems in learning and generate ideas for accomplishing tasks. In fact, higher-order thinking will increase the ability to seek alternative solutions, concepts, and actions [21]. It is, therefore, necessary for students to use and develop their high-level thinking skills to produce original ideas and complete tasks more effectively.

Taken together, the analysis results suggest that the assignments made by the lecturers of the Department of Civil Engineering Universitas Negeri Malang were fairly good since most parts elicited higher-order thinking and have complied with the IQF Level Six.

\section{CONCLUSION}

The analysis results have led to the following conclusions. First, the exam questions constructed by the lecturers of the Department of Civil Engineering, State University of Malang have fairly complied with the Indonesian Qualifications Framework Level Six, but the overall proportion of higher-order thinking questions was categorised as lacking. Second, the assignments made by the lecturers of the Department of Civil Engineering, State University of Malang were relatively good since most parts elicited higher-order thinking and have satisfied the requirements of the IQF Level Six. Thus, such assignments could adequately meet students' needs in the development of higher-order thinking skills for seeking solutions to the real problems in the future.

\section{ACKNOWLEDGEMENT}

The authors would like to thank the professors of the civil engineering department, the dean of the engineering faculty, and the rector of the State University of Malang who has supported the research, so that the completion of this article.

\section{REFERENCES}

[1] M. Gewati, "Kenapa Lulusan Perguruan Tinggi Makin Susah Mendapat Pekerjaan?,” Kompas.com. 23 April 2016, (online) (http:// edukasi.

kompas.com/read/2016/04/23/17424071/Kenapa.Lulusan.Perguruan. Tinggi.Makin.Susah.Mendapat.Pekerjaan), accessed 9 April 2017.

[2] D. Seftiawan, "Serapan Tenaga Kerja Lulusan Perguruan Tinggi Masih Rendah," Pikiran Rakyat 19 Juli 2017, (online) (http: //www.pikiran-rakyat.com/pendidikan/2017/07/19/ serapan-tenagakerja-lulusan-perguruan-tinggi-masih-rendah-405482), accessed 20 February 2018

[3] R. Sitorus, "Daya Saing SDM Rendah, Pendidikan Tinggi Perlu Direvitalisasi," Bisnis.com 18 November 2016, (online) (http:// kabar24.bisnis.com/read/20161118/255/603898/daya-saing-sdmrendah-pendidikan-tinggi -perlu-direvitalisasi), accessed 21 February 2018 .

[4] Sindo, "Kualitas Lulusan PT Masih Rendah" Koran Sindo, 20 April 2017, (online) (http://koran-sindo.com/page/ news/2017-04-20/0/16/ rubric. php? $\mathrm{r}=2$ ), accessed 21 February 2018.

[5] S. Gultom, "Kerangka Kompetensi Abad 21 dalam Implementasi Kurikulum 2013". Powerpoint pembekalan Instruktur PLPG, 5 September 2013 di Universitas Negeri Malang, Indonesia.

[6] A. Churches, 21 $1^{\text {st }}$ Century Assessment, 2009, (Online) (http:// edorigami. wikispaces. com $/ 21 \mathrm{st}+$ Century + Assessment), accessed 24 February 2015.

[7] L. Darling-Hammond, J. Herman, J. Pellegrino, J. Abedi, J.L. Aber, E. Baker, R. Bennett, E. Gordon, E. Haertel, K. Hakuta, A. Andrew Ho, R.L. Robert Lee Linn, P.D. Pearson, J. Popham, L. Resnick, A.H. Schoenfeld, R. Shavelson, L.A. Shepard, L. Shulman, C.M. Steele, Criteria for High-Quality Assessment. Center for Research on Student Standards and Testing, University of California: Los Angeles, 2013.

[8] L.W. Anderson \& D.R. Krathwohl, A Taxonomy for Learning, Teaching and Assessing: a Revision of Bloom's Taxonomy, 2001, (Online) (http://www. kurwongbss. qld.edu.au/ thinking/ Bloom/blooms.htm), accessed 25 March 2015.

[9] R. Bronk, Bloom's Taxonomy, 2009 (Online) (http://etec.ctlt.ubc.ca/ 510wiki/ index. php?title $=$ Bloom $\% 27 \mathrm{~s}$ Taxonomy\&oldid $=62298$ ), accessed 24 March 2015.

[10] J.D. Ulmer, \& R.M. Torres, "A Comparison of The Cognitive Behaviors Exhibited by Scondary Agriculture and Science Teachers," Journal of Agricultural Education, Vol. 48, pp. 106-116, 2017. DOI: $10.5032 /$ jae.2007.04106 
[11] A.Y. Zheng, J.K. Lawhorn, T. Lumley, S. Freeman, "Application of Bloom's Taxonomy Debunks the MCAT Myth," Science, Vol. 319, pp. 414-415, January 2008. DOI:10.1126/science.1147852.

[12] A.J. Swart, "Evaluation of Final Examination Papers in Engineering: A Case Study Using Bloom's Taxonomy," IEEE Transactions On Education, Vol. 53, pp. 257-264, May 2010.

[13] T. Thompson, "Mathematics Teachers' Interpretation Of HigherOrder Thinking In Bloom's Taxonomy," International Electronic Journal of Mathematics Education, Vol. 3, pp. 96-111, July 2008.

[14] Y. Abosalem, "Assessment Techniques and Student, Higher-OrderThinking Skills," International Journal of Scondary Education, Vol. 4, pp. 1-11, March 2016, DOI: 10.11648/j.ijsedu.20160401.11.

[15] F.J. King, L. Goodson, \& F. Rohani, Higher Order Thinking Skills: Definitions, strategies, assessment, 1998, (Online) (http://www. cala.fsu. edu/files/higher_order_thinking skills.pdf), accessed 10 March 2015.

[16] Perpres RI No 8, Deskripsi Jenjang Kualifikasi pada Kerangka Kualifikasi Nasional Indonesia. Kementerian Hukum dan Hak Asasi Manusia: Jakarta, 2012, pp. 1-4. (http://kkni-kemenristekdikti. org/ asset/pdf/perpres No 8 tahun 2012 ttg_kkni.pdf).

[17] P. Pramudiyanti, H. Susilo, dan M. Amin, "Analisis Tingkat Berpikir Kognitif Mahasiswa pada Pembelajaran Biologi Sel melalui
Teknik Menuliskan Pertanyaan," Seminar Nasional Pendidikan MIPA Fakultas Keguruan dan Ilmu Pendidikan Universitas Lampung, Bandar Lampung, Indonesia, Vol. 2, 2015. (Online) (https://www.researchgate. net/ publication/293517724), accessed 4 December 2017.

[18] A.N. Putri, "Tingkat Berpikir Kognitif Mahasiswa Berdasarkan Bentuk Pertanyaan pada Mata Kuliah Biologi Umum,” Prosiding Seminar Nasional Pendidikan Sains: Strategi Pengembangan Pembelajaran dan Penelitian Sains untuk Mengasah Keterampilan Abad 21. Surakarta, Indonesia, pp. 136-140, October 2017.

[19] D. Shukla and A. P. Dungsungnoen, "Student's Perceived Level and Teachers' Teaching Strategies of Higher Order Thinking Skills; A Study on Higher Educational Institutions in Thailand," Journal of Education and Practice, Vol.7, 2016, pp. 211-219, 2016.

[20] BAN-PT, Buku VI: Matriks Penilaian Instrumen Akreditasi Program Studi Sarjana. Badan Akreditasi Nasional Perguruan Tinggi: Jakarta, 2008, pp. 20

[21] Y.M. Heong, J.M. Yunos, W. Othman, R. Hassan, T.T. Kiong, and M.M. Mohamad, "The needs analysis of learning higher order thinking skills for generating ideas," Proceedia-Social and Behavioral Science, Vol. 59, pp.197-203, October 2012. DOI: 10.1016/jsbspro.212.09.265 